In the present patient the mediastinal mass was a thyroid carcinoma. In patients with normal pretracheal thyroid it is difficult to distinguish with certainty between metastasis and primary ectopic carcinoma. However, careful examination of the pretracheal thyroidectomy specimen, in addition to angiographic finding, excluded the possibility of metastasis in the mediastinum. Instead, the tumor was a primary carcinoma of ectopic mediastinal thyroid. Primary ectopic thyroid carcinoma has previously been observed rarely. ${ }^{2}$

Ectopic mediastinal thyroid and even primary thyroid carcinoma should be kept in mind when examining a patient with a mass in the upper anterior part of the mediastinum, even if the patient has a normal pretracheal thyroid gland.

\section{REFERENCES}

1. Spinner RJ, Moore KL, Gottfried, Lowe JE, Sabiston DC. Thoracic intrathymic thyroid. Ann Surg 1994;220:91-6.

2. Fish J, Moore RM. Ectopic thyroid tissue and ectopic thyroid carcinoma. Ann Surg 1963;157:212-22.

3. Larochelle D, Arcand P, Belzile M, Gagnon NB. Ectopic thyroid tissue-a review of the literature. J Otolaryngol 1979; 8:523-30.

4. Rogers WM, Kesten HD. Embryologic bases for thyroid tissues in the heart. Anat Rec 1962;142:323.

5. Randolph J, Grunt JA, Vawter GF. The medical and surgical aspects of intratracheal goiter. N Engl J Med 1963;268:45761 .

\title{
HUGE THYMIC CYSTS
}

Uğur Gönüllü, MD, Adem Güngör, MD, I̊smail Savaş, MD, Özlem Özdemir, MD, Gül Moğulkoç, MD, Doğanay Alper, MD, and Şinasi Yavuzer, MD, Ankara, Turkey

Thymic cysts are uncommon mediastinal lesions located in the anterior compartment in all age groups. They are usually asymptomatic and found incidentally on chest roentgenograms. ${ }^{1}$ Rarely the cysts cause symptoms, such as hoarseness or dyspnea, resulting from pressure on nearby organs. The cysts may be uniloculated or multiloculated, ranging in size from microscopic to enormous, almost filling an entire chest.

Five patients with thymic cyst were seen in our hospital and treated surgically (Table I). Most cysts were of moderate size, but one in a 24-year-old woman almost completely opacified the left side of the chest, measuring $30 \mathrm{~cm}$ in its greatest diameter (Fig. 1). In four patients, the

From the Departments of Respiratory Diseases and Thoracic Surgery, Medical School of Ankara University, Ankara, Turkey.

Received for publication April 20, 1995; accepted for publication Dec. 7, 1995.

Address for reprints: Uğur Gönüllü, MD, Özveren Sokak 26/1, Demirtepe Ankara, 06570 Turkey.

J Thorac Cardiovasc Surg 1996;112:835-6

Copyright (C) 1996 by Mosby-Year Book, Inc.

$0022-5223 / 96 \$ 5.00+0 \quad \mathbf{1 2 / 5 4 / 7 1 1 6 4}$ lesions could be readily excised through a thoracotomy incision; the fifth patient required median sternotomy. All patients did well in the postoperative period and were discharged from the hospital free of symptoms.

When a thymic cyst is located in the neck, a mass can be detected, which can cause dyspnea and hoarseness. Three of our patients had dyspnea or cough or both. The others were free of symptorns. These cysts may be uniloculated or multiloculated and of various sizes. To our knowledge, the largest thymic cyst previously reported was $18 \mathrm{~cm}$ in diameter and multiloculated. ${ }^{2}$ The cyst in our case 4 is the largest uniloculated cyst reported, measuring $17 \mathrm{~cm}$, and that in our case 5 is the largest multiloculated cyst $(30 \mathrm{~cm})$ reported (Table I).

On chest roentgenograms, thymic cysts look like smoothly contoured anterior mediastinal masses. A number of authors also have drawn attention to the usefulness of computed tomographic scans in evaluation of the thymus gland. ${ }^{3}$ We performed thoracic computed tomographic scans in most of our patients and the findings supported the diagnosis.

Reports of thymic cysts developing after radiotherapy have been reported. ${ }^{4}$ Neither of our patients had received radiotherapy. Thymic cysts can also form after thoracic

Table I. Features of cases of thymic cysts

\begin{tabular}{|c|c|c|c|c|}
\hline $\begin{array}{l}\text { Case No. } \\
\text { (age, sex) }\end{array}$ & Thyroid & Chest $x$-ray film & Size $(\mathrm{cm})$ & Operation \\
\hline $1(27, M)$ & Diffuse palpable & Superior mediastinal widening & 11 by 7 by 5 & Median sternotomy \\
\hline $2(38, F)$ & Nodule in isthmus & Widened upper and medial mediastinum & 8 by 5 by 4 & Thoracotomy \\
\hline $3(39, \mathrm{M})$ & Nonpalpable & Right hilar lesion & 8 by 5 & Thoracotomy \\
\hline $4(32, F)$ & Diffuse palpable & $\begin{array}{l}\text { Homogeneous lesion extending from sec- } \\
\text { ond intercostal space to base in left } \\
\text { hemithorax with calcified borders }\end{array}$ & 17 by 10 by 8 & Thoracotomy \\
\hline $5(24, F)$ & Nonpalpable & $\begin{array}{l}\text { Well-circumscribed lesion filling left } \\
\text { hemithorax with deplacement of } \\
\text { mediastinum to the right }\end{array}$ & 30 by 25 by 20 & Thoracotomy \\
\hline
\end{tabular}




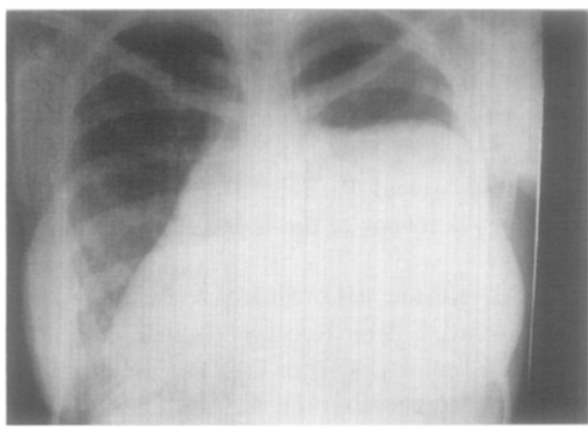

Fig. 1. Posteroanterior chest $x$-ray film showing a wellcircumscribed lesion filling the left hemithorax.

operations, but none of our patients had undergone such operations. The apparent association of thymic cysts with infection (e.g., syphilis or tuberculosis) has been reported ${ }^{2}$ but was not present in our cases. If hemorrhage occurs, fluid in the cyst becomes brownish and more viscid. In two of our patients, the cysts had such findings. Microscopic examination did not show a definite epithelium. The walls showed fibrocollagenous scar tissue formation. Malignant degeneration, although rare, has been reported ${ }^{5}$ but was not seen in this review. Some malignant tumors, particularly thymoma, Hodgkin's disease, and seminoma, can show prominent cystic changes. We therefore made every effort to detect any malignant tissue on pathologic examination. A diffuse goiter was seen in three of five patients. However, this finding may be coincidental because goiter is endemic in Turkey. This relationship should be investigated further. Operative excision of thymic cysts seems both diagnostic and curative.

Except in case 1, the thymic cysts were not localized in the midline and all were large. Therefore we preferred thoracotomies to explore and excise the cysts rather than median sternotomies. The cysts were completely removed to prevent a recurrence and to eliminate the risk of malignant transformation. Thoracotomy in patients with large cysts allows for easy removal of the cysts. Neither aspiration nor decompression of the cysts was necessary.

\section{REFERENCES}

1. Suster S, Rosai J. Multilocular thymic cyst: an acquired reactive process-study of 18 cases. Am J Surg Pathol 1991;15:388-98.

2. Bieger RC, McAdams AJ. Thymic cysts. Arch Pathol 1966;82: $535-41$.

3. Dunne MG, Weksberg AP. Thymic cyst: computed tomography and ultrasound correlation. J Comput Tomogr 1983;7:351-5.

4. Shapiro J, Gallant A, Wechsler RJ, Steiner RM. Thymic cyst secondary to cervical irradiation: a complication of treated laryngeal cancer. Comp Med Imaging Graph 1991; 5:319-22.

5. Leon AS-Y, Brown JH. Malign transformation in a thymic cyst. Am J Surg Pathol 1984;8:471.

\section{CORONARY ARTERIES ARISING FROM THE CONTRALATERAL AORTIC SINUS: ELECTRON BEAM COMPUTED TOMOGRAPHIC DEMONSTRATION OF THE INITIAL COURSE OF THE ARTERY WITH RESPECT TO THE AORTA AND THE RIGHT VENTRICULAR OUTFLOW TRACT}

Elie Mousseaux, MD, $\mathrm{PhD},{ }^{\mathrm{a}, \mathrm{b}}$ Anne Hernigou, MD, ${ }^{a}$ Marc Sapoval MD, ${ }^{a}$ Olivier Darmon, $\mathrm{MD},{ }^{\mathrm{c}}$ Bernard Beyssen MD, ${ }^{a}$ and Jean-Claude Gaux, MD, ${ }^{a}$ Paris, France

The variations in the initial course of a coronary artery with an abnormal origin are more important than the abnormal origin itself. Certain of these variations are associated with sudden death, myocardial infarction, or angina pectoris when the left main coronary artery or the right coronary artery passes between the aorta and the pulmonary trunk. ${ }^{1}$ The relationship between the initial course of the aberrant coronary artery and the aorta and

From the Department of Cardiovascular Radiology, ${ }^{a}$ INSERM U66, ${ }^{b}$ and the Department of Cardiology ${ }^{\mathrm{c}}$ Hôpital Broussais, Paris, France.

Received for publication Dec. 7, 1995; accepted for publication Feb. 29, 1996.

Address for reprints: Elic Mousseaux, MD, PhD, Service de Radiologie Cardiovasculaire, Hôpital Broussais, 96 rue Didot, 75014 Paris, France.

J Thorac Cardiovasc Surg 1996;112:836-40

Copyright (1) 1996 by Mosby-Year Book, Inc.

$0022-5223 / 96 \$ 5.00+0 \quad \mathbf{1 2 / 5 4 / 7 3 2 3 4}$ the right ventricular outflow tract, however, can be diffcult to assess by coronary angiography. Electron beam computed tomography (EBCT) and magnetic resonance imaging have recently shown potential in the visualization of the coronary arteries. ${ }^{2,3}$ This report describes six cases in which the initial courses of the left main coronary artery, originating in the right sinus of Valsalva, or the right coronary artery, originating from the left sinus, were clearly detailed with EBCT.

Case histories and EBCT results. In three cases with the left main coronary artery arising from the right aortic sinus, EBCT detected the initial course of the abnormal coronary artery with respect to the right ventricular outflow tract. The passage of the artery between the aorta and the pulmonary trunk was found in one patient admitted to intensive care for an extensive acute anterior myocardial infarction (Fig. 1). Coronary arteriography showed the left main coronary artery arising from the initial part of the right coronary artery in the second case. EBCT examination (Fig. 2) depicted the intramyocardial tunneling of the left main coronary artery within the 